\title{
EFFECTS OF TWO GROWTH REGULATORS ON YIELD AND YIELD ATTRIBUTES OF TWO VARIETIES OF WHEAT (TRITICUM AESTIVUM L.)
}

\author{
Rifat-Ahmed, Quazi Abdul Fattah and Nargis Jahan \\ Department of Botany, University of Dhaka, Dhaka-1000, Bangladesh \\ Key words: KNap, Mixtalol, Yield attributes, Wheat, Foliar application
}

\begin{abstract}
Foliar applications of 500 and 1000 ppm KNap and 2 and 4 ppm mixtalol on Kanchan and Akbar varieties of wheat showed that in most cases spikelets per plant, grains per spikelet, weight of 1000 grains and grain yield per plant increased significantly. In Kanchan the highest yield was due to 4 ppm mixtalol and in Akbar it was due to 500 ppm KNap.
\end{abstract}

Wheat (Triticum aestivum L.) is the second most important crop, next only to rice, in Bangladesh. It is a major source of carbohydrate, protein, vitamins, minerals and a number of essential amino acids to humans. Wheat contributes more calories and more protein to the world's diet than any other food crop (Purseglove 1975). So, its cultivation area and production per unit area should be increased. The use of growth regulators is considered as one of the ways for such an attempt. In many countries experiments have been carried out to investigate effects of potassium salt of naphthenic acid, potassium naphthenate (KNap), on the yield and quality of wheat (Shaki-Zade 1963, Popoff and Boikov 1966). But in Bangladesh no information is available on the effect of KNap on any variety of wheat. Mixtalol, a mixture of a long chain $\mathrm{C}_{24}$ to $\mathrm{C}_{34}$ (aliphatic alcohols), has been reported to increase the productivity of a number of crop plants viz. maize (Jain et al.1987a), wheat (Jain et al. 1987b), rice (Thangamuthu 1987), sorghum (Yousuf et al. 1987). The present investigation was carried out to study the effect of two plant growth regulators, KNap (500 and $1000 \mathrm{ppm})$ and mixtalol (2 and $4 \mathrm{ppm}$ ) on the yield and yield attributes of Kanchan and Akbar varieties of wheat.

The experiment was conducted in the Botanical garden, Dhaka University using Kanchan $\left(\mathrm{V}_{1}\right)$ and Akbar $\left(\mathrm{V}_{2}\right)$ varieties of wheat. The seeds were collected from BARI, Joydebpur. There were five treatments in the experiment as follows; $T_{0}=$ control (water), $T_{1}=500 \mathrm{ppm} \mathrm{KNap,} \mathrm{T}_{2}=1000$ ppm KNap, $\mathrm{T}_{3}=2 \mathrm{ppm}$ mixtalol and $\mathrm{T}_{4}=4 \mathrm{ppm}$ mixtalol. All the treatments were as foliar spray. Randomized complete block design was followed for the experiment with four replications for each treatment. The field was divided into 20 subplots of $2.5 \mathrm{~m} \times 0.7 \mathrm{~m}$, having $50 \mathrm{~cm}$ spaces in between plots. Each subplot had 100 plants in four rows. Recommended doses of fertilizers and normal management practices were followed. Yield parameters were determined at maturity stage. Data collected on different parameters were statistically analyzed and treatment means were compared by LSD test (Steel and Torrie 1960).

Highly significant increase in the number of spikelets per plant were found in both the varieties applying $500 \mathrm{ppm} \mathrm{KNap}$ and $4 \mathrm{ppm}$ mixtalol. The highest number of spikelets per plant, was recorded in Akbar treated with $500 \mathrm{ppm}$ KNap followed by $4 \mathrm{ppm}$ mixtalol (Table 1). Due to $1000 \mathrm{ppm}$ KNap and $2 \mathrm{ppm}$ mixtalol, increases in the number of spikelets per plant were also significant (Table 1). Similar results of increased number of spikelets, cob or panicles per plant due to KNap treatment have been reported in maize (Yur'eva 1965, Fattah and Khatun 1974), wheat (Shaki-Zade 1963, Popoff and Boikov 1966), rice (Fattah et al. 1975, Hossain and Fattah 1990) and Italian millet (Fattah et al. 1982), and mixtalol treatments maize (Jain et al. 1987a), 
wheat (Jain et al. 1987b) and rice (Thangamuthu 1987). The length of spikelets in both the wheat varieties were not affected by the growth regulators (Table 1 ).

Results indicated that number of grains per spikelet of wheat plant increased significantly following 2 and $4 \mathrm{ppm}$ mixtalol, and $500 \mathrm{ppm}$ KNap treatments in both the varieties, whereas, increase due to $1000 \mathrm{ppm}$ KNap was non-significant in Kanchan. The maximum number of grains per spikelet, 50.92, was obtained from $4 \mathrm{ppm}$ mixtalol treated Akbar variety (Table 1). The results obtained conform with the findings of Fattah et al. (1975) on rice, Fattah and Khatun (1974) on maize, Fattah et al. (1982) on Italian millet, Yousuf et al. (1987) on sorghum, Jain et al. (1987b) on wheat. However, response of Akbar was better than Kanchan for both the growth regulators.

Table 1. Effect of KNap and mixtalol on yield and yield attributes of Kanchan and Akbar. $\mathbf{n}=\mathbf{2 0}$.

\begin{tabular}{cccccc}
\hline Treatments & $\begin{array}{c}\text { No. of } \\
\text { spikelets/plant }\end{array}$ & $\begin{array}{c}\text { Length of } \\
\text { spikelet }\end{array}$ & $\begin{array}{c}\text { No. of } \\
\text { grains/ spikelet }\end{array}$ & $\begin{array}{c}100 \text { grain } \\
\text { weight }(\mathrm{g})\end{array}$ & $\begin{array}{c}\text { Grain } \\
\text { yield/plant }(\mathrm{g})\end{array}$ \\
\hline $\mathrm{V}_{1} \mathrm{~T}_{0}$ & $2.40 \mathrm{e}$ & 10.49 & $40.25 \mathrm{e}$ & $4.39 \mathrm{de}$ & $5.14 \mathrm{f}$ \\
$\mathrm{V}_{1} \mathrm{~T}_{1}$ & $3.80 \mathrm{ab}$ & 10.71 & $45.25 \mathrm{bc}$ & $5.77 \mathrm{a}$ & $6.73 \mathrm{~b}-\mathrm{d}$ \\
$\mathrm{V}_{1} \mathrm{~T}_{2}$ & $2.60 \mathrm{de}$ & 10.13 & $40.67 \mathrm{e}$ & $5.09 \mathrm{bc}$ & $5.49 \mathrm{ef}$ \\
$\mathrm{V}_{1} \mathrm{~T}_{3}$ & $3.10 \mathrm{~cd}$ & 10.57 & $44.75 \mathrm{~cd}$ & $5.19 \mathrm{~b}$ & $6.08 \mathrm{c}-\mathrm{f}$ \\
$\mathrm{V}_{1} \mathrm{~T}_{4}$ & $4.18 \mathrm{ab}$ & 10.76 & $47.75 \mathrm{a}-\mathrm{c}$ & $6.01 \mathrm{a}$ & $7.96 \mathrm{a}$ \\
$\mathrm{V}_{2} \mathrm{~T}_{0}$ & $2.65 \mathrm{de}$ & 09.73 & $41.83 \mathrm{de}$ & $4.11 \mathrm{e}$ & $5.61 \mathrm{~d}-\mathrm{f}$ \\
$\mathrm{V}_{2} \mathrm{~T}_{1}$ & $4.29 \mathrm{a}$ & 10.47 & $49.83 \mathrm{a}$ & $4.94 \mathrm{~b}-\mathrm{d}$ & $7.98 \mathrm{a}$ \\
$\mathrm{V}_{2} \mathrm{~T}_{2}$ & $3.50 \mathrm{bc}$ & 10.58 & $48.92 \mathrm{a}$ & $4.57 \mathrm{c}-\mathrm{e}$ & $7.02 \mathrm{a}-\mathrm{c}$ \\
$\mathrm{V}_{2} \mathrm{~T}_{3}$ & $3.01 \mathrm{c}-\mathrm{e}$ & 10.16 & $48.00 \mathrm{ab}$ & $4.64 \mathrm{~b}-\mathrm{e}$ & $6.53 \mathrm{~b}-\mathrm{e}$ \\
$\mathrm{V}_{2} \mathrm{~T}_{4}$ & $4.25 \mathrm{a}$ & 10.43 & $50.92 \mathrm{a}$ & $5.12 \mathrm{bc}$ & $7.38 \mathrm{ab}$ \\
\hline LSD 0.05 & 0.64 & $\mathrm{NS}$ & 3.18 & 0.55 & 1.2 \\
$\mathrm{CV} \%$ & 18.4 & 5.4 & 21.6 & 4.8 & 22.0 \\
\hline
\end{tabular}

Means followed by the same alphabet in a vertical column do not differ significantly at $5 \%$ level.

Weight of 100 grains is an index of grain size and is also related to the grain yield (Hardwick and Milbourn 1967, Kambel 1969). In both the varieties, 100 grain weight increased significantly due to 500 and $1000 \mathrm{ppm} \mathrm{KNap}$ and $4 \mathrm{ppm}$ mixtalol treatments. The increase due to 500 and 1000 ppm KNap were 31.44 and $15.95 \%$ in the variety Kanchan, and 20.19 and $11.19 \%$ in the variety Akbar, respectively. The results also showed that weight of 100 grains increased by 18.22 and $36.90 \%$ due to 2 and 4 ppm mixtalol, respectively in Kanchan and 12.89 and 24.57\% following 2 and $4 \mathrm{ppm}$ mixtalol in Akbar, respectively. Fattah and Khatun (1974), Fattah et al. (1982), Hossain and Fattah (1990), Jain et al. (1987b), Yousuf et al. (1987) also reported increase in seed weight per plant of maize, Italian millet, rice, wheat and sorghum plants, respectively due to KNap and mixtalol treatments.

Grain yield per plant increased significantly due to $500 \mathrm{ppm}$ KNap treatment in both the varieties of wheat. The highest increase recorded was $42.25 \%$ in Akbar. Due to 1000 ppm KNap treatment the grain yield increased significantly only in Akbar and it was $25.13 \%$ over the control. The results are in agreement with the findings of Fattah et al. (1975) and Hossain and Fattah (1990) on rice, Fattah and Khatun (1974) on maize, Fattah et al. (1982) on Italian millet. Grain yield per plant also increased following foliar application of both the concentrations of mixtalol. Following $4 \mathrm{ppm}$ mixtalol treatment the increase was 54.86\% over the control in Kanchan and $31.55 \%$ in Akbar. Due to $2 \mathrm{ppm}$ mixtalol treatment the increase was significant only in Akbar. 
Increase in yield following mixtalol application had been reported by Jain et al. (1987a), Thangamuthu (1987) and Jain et al. (1987b) on maize, rice and wheat, respectively.

Thus, analysis of the data indicate that, in both the varieties of wheat, out of two treatments of KNap, $500 \mathrm{ppm}$ produced better stimulations. Treatment with $4 \mathrm{ppm}$ mixtalol was also more effective than $2 \mathrm{ppm}$ mixtalol. However, in Kanchan, the highest increase was recorded from plants treated with $4 \mathrm{ppm}$ mixtalol, but in the variety Akbar, it was due to $500 \mathrm{ppm}$ KNap treatment. The results are consistent with the view that the plant growth regulators (PGR) can exert quite different effects in different plants, and sometime the same PGR can elicit different effects on different tissues within the same plant (Ridge 1991).

\section{References}

Fattah Q.A. and H. Khatun. 1974. Effect of Potassium naphthenate and Gibberellic acid on the grain yield of miaze (Zea mays L.cv. Deshi). Bangladesh J. Bot 3(1): 11-18.

Fattah Q.A., M.K. Pasha and A.U. Mallik. 1975. Effect of Potassium naphthenate on the yield of IR-8 rice. Bangladesh J. Bot. 4(1-2): 73-77.

Fattah Q.A., S. Huq and A. Rahman 1982. Yield responses of Italian millet (Setaria italica L. Beauv). cv. Kaon Shibnagar to Potassium naththenate application. Bangladedsh J. Bot. 11(2): 176-178.

Hardwick R.C. and G.M. Milbourn. 1967. Yield analysis in the vining peas. Agric. Prong. 42: 24-31.

Hossain F. and Q.A. Fattah. 1990. Grain yield of rice (Oryza sativa L.) following potassium naphthenate treatment. Bangladesh J. Life Sci. 3: 13-18.

Jain G.L., G.L. Sharma and P.S. Rao. 1987a. Response of maize to some new plant growth stimulants at varying levels of nitrogen. In: Crop productivity, H.C. Srivastava, S. Bhaskaran \& RKG Menon (Eds), pp. 153-168. Proc. workshop on 'Increasing crop productivity', Bombay.

Jain G.L., S.M. Singhi and I. Singh. 1987b. Effect of Mixtalol (Paras Photosynth) under varying nitrogen level on wheat production. In: Crop. Productivity (Srivastava HC, S Bhaskaran \& RKG Menon Eds), pp. 135-143. Proc. workshop on 'Increasing crop productivity', Bombay.

Kambel A.E. 1969.Components of yield in field bean (Vicia faba L.). J. Agric.Sci. Cambridge 72: 359-363.

Popoff M.D. and A.D. Boikov. 1996. Testing the stimulation effect of naphthenic growth substances (NGS) on plants. Symp. Plant stimulation. pp. 119-120. Sofia.

Purseglove J.W. 1975. Tropical crops. Monocotyledons Vol. 1 and 2 combined. Longmanns.

Ridge I. (Ed.). 1991. Plant Physiology. pp. 225-281. Hodder \& Stoughton, Kent.

Shaki-Zade M.G. 1963. Industrial production of naphthenic growth substance. Neftepererabotkai Negtekhim. Nauch-Tekhn. Sb. 24-27; Chem. Abst. 61: 5431e. 1964.

Steel R.G.D. and J.H. Torrie. 1960. Principles and procedures of statistics. McGraw-Hill, New York.

Thangamuthu GS. 1987. Influence of Mixtalol on rice production. In: Crop productivity, H.C. Srivastava, S. Bhaskaran \& R.K.G. Menon (Eds), pp. 145-148. Proc. workshop on increasing crop productivity', Bombay.

Yousuf L.A., G.L. Jain and G.L. Sharma. 1987. Effect of Mixtalol (paras photosynth) with nitrogen levels on sorghum (Sorghum bicolor (L.) Moench). In: Crop productivity. H.C. Srivastava, S. Bhaskaran \& R.K.G. Menon (Eds), pp. 160-178. Proc. workshop on 'Increasing crop productivity', Bombay.

Yur'eva K.V. 1965. Results of using petroleum growth promoting substances in plant growing. Dokl. Vses. Soveshch. Primen. Neft. Rostovogo Veschestva Sel. Knoz., $2^{\text {nd }}$ Baku (1963), pp. 443-447. 